\title{
Comparative Analysis of the Health of Government-Owned Banks (Persero) During the COVID 19 Period (Case Study at PT Bank Mandiri Tbk)
}

Sri Kurniawati ${ }^{1 *}$, Muhammad Laras Widyanto ${ }^{2}$, Herminda $^{1}$, Rahayu Endang Suryani ${ }^{1}$

${ }^{1}$ Universitas Persada Indonesia YAI, Jakarta, Indonesia

${ }^{2}$ Universitas Mercu Buana, Jakarta, Indonesia

\section{Article History \\ Received: 11.12.2021 \\ Accepted: 16.01.2022 \\ Published: 19.01.2022}

Journal homepage: https://www.easpublisher.com

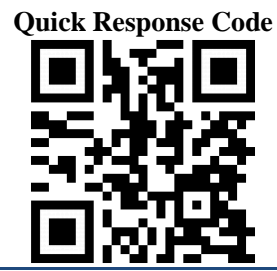

Abstract: Bank Mandiri won the best Financial Services Super App at the CNBC Indonesia Awards 2021 during the covid 19 pandemic. This study is to determine whether there are differences in bank performance before and after the covid pandemic. The methodology used is the Wilcoxon difference test because the data are not normally distributed. The results of statistical analysis state that there is no difference in bank performance or health at Bank Mandiri between before and after the COVID-19 pandemic.

Keywords: Bank, Bank Health and Performance.

Copyright (C) 2022 The Author(s): This is an open-access article distributed under the terms of the Creative Commons Attribution 4.0 International License (CC BY-NC 4.0) which permits unrestricted use, distribution, and reproduction in any medium for non-commercial use provided the original author and source are credited.

\section{INTRODUCTION}

CNBC Indonesia held the CNBC Indonesia Awards 2021 as a form of appreciation and performance achieved by economic players and the business world throughout 2021 with the theme "Indonesian Economic Awakening 2022". CNBC Indonesia Awards 2021 awarded PT Bank Mandiri (Persero) Tbk (BMRI) as 'The Best Financial Services Super App' (CNBC, 2021).

The performance of PT Bank Mandiri Tbk (BMRI) in 2020 is in accordance with the projections of many parties. The economic slowdown due to the Covid-19 pandemic that has emerged since March 2020 has eroded the bank's net profit quite deeply. The decrease in interest income and the increase in reserves to anticipate credit risk are the causes of depressed bank profits this year. Over the past year, this state-owned bank was only able to record a net profit of Rp. 17.1 trillion. Down $37.71 \%$ compared to the previous year (year on year/YoY) (Hutauruk DM \& Mahadi. T, 2021).

Rahmaniah and Wibowo (2015) stated that the year 2011 to 2013 on the third BUS (Islamic Banks) nothing is declared unhealthy and potentially high financial distress, the three BUS experienced a decline in the performance of earnings as measured by ROA and ROE and liquidity ratios. Pramana and Artini (2016) stated that during the period of 2011 to 2014 Bank Danamon always ranked 1 or very healthy. Calculation of the NPL ratio and LDR illustrates that the bank has managed the risk well. GCG assessment shows that corporate governance has been done well. Calculation of ROA and NIM shows the ability of banks to achieve high profits. Calculation of CAR is always above the minimum limit of Bank Indonesia deemed able to manage its capital (Pramana and Artini, 2016). .The results stated the performance bank of PT Bank MNC International Tbk is not the difference between performance in 2017 and performance bank in 2018 (Faizal H, \& Sari A). Wahyuningsih. D \& Gunawan. R, 2017) stated that thus BOPO (Operating Expenses and Operating Income) and liquidity (loan deposit ratio) simultaneously significant return to profitability on assets. Wahyuningsih. D \& Gunawan. R (2017) stated that there was a significant difference in the ratio of LDR, ROA, CAR, BOPO and not significant in the ratio of ROE and NPL in conventional banks and sharia banks. Putri, YF 2015), Riadi, et al., (2016) stated that the soundness of banks in 2013 to 2015 from the risk profile aspect was classified as very healthy, Good Corporate Governance was quite healthy, earnings were very healthy, and Capital was very healthy. Helsinawati (2018) stated that it had different performance of Bank DKI between 2016 and 2017. This study analyze Bank 
Sri Kurniawati et al, East African Scholars J Econ Bus Manag; Vol-5, Iss-1 (Jan, 2022): 11-15

Mandiri Performance (Health) before Covid 19 (year 2019) and after Covid 19 (year 2020) comparatively.

\section{MATERIALS AND METHODS}

The Bank is considered as a financial institution perform various financial activities (Ismail, 2016). Bank Health is the competence of a capable bank carrying out its activities inaccordance with applicable regulation (Fitrawati, Saifi \& Zahro, 2016)

\section{RESULTS AND DISCUSSION 3.1. RESULT}

Bank Mandiri was established on October 2, 1998, as part of the banking restructuring program implemented by the Indonesian government. In July 1999, four state-owned banks, namely Bank Bumi Daya, Bank Dagang Negara, Bank Export Import Indonesia and Bank Pembangunan Indonesia were merged into Bank Mandiri, each of which has an integral role in the development of the Indonesian economy. To this day, Bank Mandiri continues the tradition of more than 140 years of contributing to the banking world and the Indonesian economy (Bank Mandiri, 2021) (Profile www.bankmandiri.co.id.)

Table 1: Bank Mandiri performance

\begin{tabular}{|l|l|l|}
\hline Health Performance of Mandiri Bank & $\begin{array}{l}\text { After Covid 19 } \\
\text { (FY 2020) }\end{array}$ & $\begin{array}{l}\text { Before Covid 19 } \\
\text { (FY 2019) }\end{array}$ \\
\hline 1. Capital Adequacy Ratio & 19,9 & 21,39 \\
\hline $\begin{array}{l}\text { 2. Non-performing productive assets and non-productive assets } \\
\text { to total productive assets and non-productive assets }\end{array}$ & 1,91 & 1,68 \\
\hline 3. Non-performing productive assets to total productive assets & 2,36 & 2,15 \\
\hline $\begin{array}{l}\text { 4. Allowance for impairment losses (CKPN) of financial assets } \\
\text { against earning assets }\end{array}$ & 5,36 & 2,88 \\
\hline 5. NPL gross & 3,29 & 2,39 \\
\hline 6. NPL net & 0,43 & 0,84 \\
\hline 7. Return on Asset (ROA) & 1,64 & 3,03 \\
\hline 8. Return on Equity (ROE) & 9,36 & 15,08 \\
\hline 9. Net Interest Margin (NIM) & 4,48 & 5,46 \\
\hline 10. Operating Expenses to Operating Income (BOPO) & 80,03 & 67,44 \\
\hline 11. Cost to Income Ratio (CIR) & 44,89 & 42,25 \\
\hline 12. Loan to Deposit Ratio (LDR) & 82,95 & 96,37 \\
\hline
\end{tabular}

Source: Financial Services Authority (2020, 2021)

The data above is bank performance data before and after covid 19, where data before covid 19 was taken from bank Mandiri performance data in
2019, while data after covid 19 was taken from bank Mandiri performance data in 2020.

Table 2: Validation test

\begin{tabular}{|c|c|c|c|c|c|c|c|}
\hline \multicolumn{8}{|c|}{ Case Processing Summary } \\
\hline & \multirow[b]{3}{*}{ Time } & \multicolumn{6}{|c|}{ Cases } \\
\hline & & \multicolumn{2}{|c|}{ Valid } & \multicolumn{2}{|c|}{ Missing } & \multicolumn{2}{|c|}{ Total } \\
\hline & & N & Percent & $\mathrm{N}$ & Percent & $\mathrm{N}$ & Percent \\
\hline \multirow[t]{2}{*}{ Performance } & After Covid19 & 12 & $100.0 \%$ & 0 & $0.0 \%$ & 12 & $100.0 \%$ \\
\hline & Before Covid19 & 12 & $100.0 \%$ & 0 & $0.0 \%$ & 12 & $100.0 \%$ \\
\hline
\end{tabular}

Based on the table above that 12 data after covid is $100 \%$ valid, and 12 data before covid is $100 \%$ valid

Table 3: Normality Test

\begin{tabular}{|c|c|c|c|c|c|c|c|}
\hline \multicolumn{8}{|c|}{ Tests of Normality } \\
\hline & \multirow[b]{2}{*}{ Time } & \multicolumn{3}{|c|}{ Kolmogorov-Smirnov ${ }^{a}$} & \multicolumn{3}{|c|}{ Shapiro-Wilk } \\
\hline & & Statistic & df & Sig. & Statistic & df & Sig. \\
\hline \multirow[t]{2}{*}{ Performance } & After Covid19 & .319 & 12 & .001 & .692 & 12 & .001 \\
\hline & Before Covid19 & .283 & 12 & .009 & .721 & 12 & .001 \\
\hline
\end{tabular}


Sri Kurniawati et al, East African Scholars J Econ Bus Manag; Vol-5, Iss-1 (Jan, 2022): 11-15

Wilcoxon test.

Based on the normality test data after covid and before covid the data is not normally distributed so use the

Table 4: Descriptive test

\begin{tabular}{|c|c|c|c|c|c|}
\hline \multicolumn{6}{|c|}{ Descriptives } \\
\hline & Time & & & Statistic & Std. Error \\
\hline \multirow[t]{26}{*}{ Performance } & \multirow[t]{13}{*}{ After Covid19 } & \multicolumn{2}{|l|}{ Mean } & 21.3833 & 8.86301 \\
\hline & & \multirow{2}{*}{$\begin{array}{l}95 \% \text { Confidence Interval } \\
\text { for Mean }\end{array}$} & Lower Bound & 1.8760 & \\
\hline & & & Upper Bound & 40.8907 & \\
\hline & & \multicolumn{2}{|l|}{$5 \%$ Trimmed Mean } & 19.1270 & \\
\hline & & \multicolumn{2}{|l|}{ Median } & 4.9200 & \\
\hline & & \multicolumn{2}{|l|}{ Variance } & 942.635 & \\
\hline & & \multicolumn{2}{|l|}{ Std. Deviation } & 30.70237 & \\
\hline & & \multicolumn{2}{|l|}{ Minimum } & .43 & \\
\hline & & \multicolumn{2}{|l|}{ Maximum } & 82.95 & \\
\hline & & \multicolumn{2}{|l|}{ Range } & 82.52 & \\
\hline & & \multicolumn{2}{|l|}{ Interquartile Range } & 36.62 & \\
\hline & & \multicolumn{2}{|l|}{ Skewness } & 1.509 & .637 \\
\hline & & \multicolumn{2}{|l|}{ Kurtosis } & .825 & 1.232 \\
\hline & \multirow[t]{13}{*}{ Before Covid19 } & \multicolumn{2}{|l|}{ Mean } & 21.7467 & 8.99978 \\
\hline & & \multirow{2}{*}{$\begin{array}{l}95 \% \text { Confidence Interval } \\
\text { for Mean }\end{array}$} & Lower Bound & 1.9383 & \\
\hline & & & Upper Bound & 41.5550 & \\
\hline & & \multicolumn{2}{|l|}{$5 \%$ Trimmed Mean } & 18.7624 & \\
\hline & & \multicolumn{2}{|l|}{ Median } & 4.2450 & \\
\hline & & \multicolumn{2}{|l|}{ Variance } & 971.952 & \\
\hline & & \multicolumn{2}{|l|}{ Std. Deviation } & 31.17614 & \\
\hline & & \multicolumn{2}{|l|}{ Minimum } & .84 & \\
\hline & & \multicolumn{2}{|l|}{ Maximum } & 96.37 & \\
\hline & & \multicolumn{2}{|l|}{ Range } & 95.53 & \\
\hline & & \multicolumn{2}{|l|}{ Interquartile Range } & 34.82 & \\
\hline & & \multicolumn{2}{|l|}{ Skewness } & 1.691 & .637 \\
\hline & & \multicolumn{2}{|l|}{ Kurtosis } & 2.056 & 1.232 \\
\hline
\end{tabular}

The data before covid means $21.3833 \%$ and the mean before covid is $21.7467 \%$

Table 5: Wilcoxon Signed Ranks Test

\begin{tabular}{|c|c|c|c|c|}
\hline \multicolumn{5}{|c|}{ Ranks } \\
\hline & & N & Mean Rank & $\begin{array}{l}\text { Sum of } \\
\text { Ranks }\end{array}$ \\
\hline \multirow{4}{*}{$\begin{array}{l}\text { Before Covid19 - After } \\
\text { Covid19 }\end{array}$} & Negative Ranks & $6^{a}$ & 5.83 & 35.00 \\
\hline & Positive Ranks & $6^{\mathrm{b}}$ & 7.17 & 43.00 \\
\hline & Ties & $0^{c}$ & & \\
\hline & Total & 12 & & \\
\hline \multicolumn{5}{|c|}{ a. Before Covid19 < After Covid19 } \\
\hline \multicolumn{5}{|c|}{ b. Before Covid19 > After Covid19 } \\
\hline \multicolumn{5}{|c|}{ c. Before Covid19= After Covid19 } \\
\hline
\end{tabular}

In the Ranks table above, there are 6 negative data ranks with a means rank of $5.83 \%$ and 6 positive data ranks with a means rank of $7.17 \%$. 


\begin{tabular}{|c|c|}
\hline \multicolumn{2}{|c|}{ Table 6: Wilcoxon Test } \\
\hline \multicolumn{2}{|c|}{ Test Statistics $^{a}$} \\
\hline & $\begin{array}{c}\text { Before } \\
\text { Covid19- } \\
\text { After Covid19 }\end{array}$ \\
\hline$z$ & $-.314^{b}$ \\
\hline Asymp. Sig. (2-tailed) & .754 \\
\hline $\begin{array}{l}\text { a. Wilcoxon Signed } \\
\text { b. Based on negati }\end{array}$ & a. Wilcoxon Signed Ranks Test \\
\hline
\end{tabular}

The Wilcoxon test results obtained a sig (2tailed) of 0.754 which means that there is no difference in the performance of PT Bank Mandiri (Persero) Tbk between before and after covid 19 .

\subsection{DISCUSSION}

Based on the results of the research, it was found that there was no difference in bank performance before and after covid 19 at PT bank Mandiri Tbk, this is in line with the research of Helsinawati et al., (2018), Faizal \& Sari (2019).

Although there is no difference, it is not stable performance because there are decreases in 6 financial ratios and 6 increases in financial ratios.

\section{CONCLUSION AND RECOMMENDATION 4.1. CONCLUSION}

Based on the results of research that there is no difference in performance or level of bank health (soundness) at Bank Mandiri before covid 19 (year 2019) and after covid 19 (year 2020) comparatively. However but it is not constant because there are 6 ratios that have experienced an insignificant increase in Bank Mandiri's financial ratios, and 6 ratios that have decreased which is not significant.

\subsection{RECOMMENDATIONS}

Based on the conclusions above, it is expected that PT Bank Mandiri Tbk in next years can improve its financial performance.

\section{REFERENCES}

- CNBC Indonesia. (2021). Bank Mandiri Wins 'The Best Financial Services Super App' CNBC Indonesia TV, CNBC IndonesiaNEWS 14 December 2021 20:51 Jakarta, CNBC Indonesia.

- Hutauruk, D. M., \& Mahadi, T. (2021). This is the result of Bank Mandiri's performance in 2020 and this year's business plan. Thursday, January 28, 2021/18:14

WIB.www.kontan.co.id KONTAN/Carolus.

- Rahmaniah, M., \& Wibowo, H. (2015). Analysis of the Potential Occurrence of Financial Distress in Islamic Commercial Banks (BUS) in Indonesia, Jurnal Islamic Economics and Banking, (1), 1-20.
- Pramana, K. M., \& Artini, L. G. S. (2016). Analysis of Bank Soundness Level (RGEC Approach) at PT Bank Danamon Indonesia Tbk, Unud Management E-Jurnal, 5(6), 3849-3878,

- Setyaningsih, A., \& Utami, ST (2013). Comparative analysis of the financial performance of Islamic banking with conventional banking, Journal of Economics and Entrepreneurship.

- Faizal, H., \& Sari, A. (2019). Analysis Comparative Between 2017 and 2018 for performance of PT Bank MNC International Tbk, East african Journal of Economic , Business and Management, 2(10), 646-648.

- Wahyuningsih, D., \& Gunawan, R. (2017). The Effect of Efficiency Level (BOPO) and Liquidity Capability (LDR) in Assessing Performance (ROA) of Banks Listed on the IDX. Scientific Journal of Management and Business. Management Study Program, Faculty of Economics and Business, Mercu Buana University, 3(3), 420-431.

- Putri, Y. F. (2015). Comparative analysis of the financial performance of commercial banks and Islamic banks, Journal of Economics 11, Journal of the Faculty of Economics, Management Study Program, University of Jember.

- $\quad$ Riadi, K. S., Atmadja, A. T., \& Wahyuni, M. A. (2016). Assessment of the Bank's Soundness Level using the RGEC (Risk Profile, Good Corporate Governance, Earnings, and Capital) method at PT. Bank Mandiri (Persero), Tbk period 20132015, JIMAT (Accounting Student Scientific Journal). e-Journal S1 Ak. Ganesha University of Education, 6(3) 2016.

- Helsinawati., Widyanto, M. L., \& Viciwati. (2018). Comparative Analysis of Bank DKI Financial for the Period in 2016 and 2017, Scholars Bulletin (Economics) Scholars Middle East, 4(6), 208-214.

- Ismail, 2016, Banking Management From Theory Towards Applications, Prenada Media.

- Fitrawati, Saifi, M., \& Zahroh. (2016) Application of the RGEC (Risk Profile, Good Corporate, Earning, Capital) application in Analyzing Bank Performance to Determine Bank Soundness Level 
Sri Kurniawati et al, East African Scholars J Econ Bus Manag; Vol-5, Iss-1 (Jan, 2022): 11-15

(Case Study of PT Bank Tabungan Negara

(Persero) Tbk 2013-2015 period, Journal of Administration Business, 37(1), 30.

- Bank Mandiri,

Profile. www.bankmandiri.co,id
- Financial Services Authority, 2020. Banking Financial Report of PT Bank Mandiri Tbk 2019.

- Financial Services Authority 2021 Banking Financial Report PT Bank Mandiri Tbk 2020.

Cite This Article: Sri Kurniawati, Muhammad Laras Widyanto, Herminda, Rahayu Endang (2022). Comparative Analysis of the Health of Government-Owned Banks (Persero) During the COVID 19 Period (Case Study at PT Bank Mandiri Tbk). East African Scholars J Econ Bus Manag, 5(1), 11-15. 